\author{
Piotr Grobelny \\ PCC Rokita SA \\ piotr.grobelny@pcc.eu
}

\title{
Safety of Chemical - storage of hazardous materials on multimodal container terminals
}

\begin{abstract}
Multimodal transport is still growing sector of economic activity in Poland. In 2015, transported in this way, more than 10 million tons of goods, an increase compared to 2014 by $7.5 \%$. According to the Railway Transport Office (RTO) Multimodal Transportation in Poland constitute only $2.37 \%$ of commodity mass transported by rail and $4.53 \%$ made by her carriage transport work, which in comparison with other countries puts Poland on one of the last places in Europe. According to the forecasts of the RTO share of intermodal transport in the Polish railway market in the years 2003-2020 will increase from $1 \%$ to almost $6 \%$. The increase in the commodity mass passing through the container terminals carries an increased risk of major failure involving dangerous chemicals. The question then arises: how to take care of the appropriate level of security acceptable to the general public.
\end{abstract}

Keywords: Safety of Chemical; Container Terminal; Hazardous Materials

At first, check whether the multimodal container terminal meets the conditions set out in the Law on Environmental Protection, qualifying it depending on the type, category and quantity of dangerous substances contained in the plant is considered to be a plant with an increased risk of failure, hereinafter referred to as "plant at increased risk" ZZR, or the establishment of a high risk of failure, hereinafter referred to as "plant at high risk" ZDR. According to the art. 3 points. 48) Environmental Protection Act, the term permanent establishment shall mean one or several installations with the area, to which the operator holds legal title, and located on the devices. On the other hand, the installations in accordance with paragraph. 6) Article. 3 Environmental Protection Act means:

a) a stationary technical device,

b) a group of stationary technical devices related technology to which legal title has the same entity and located in one plant,

c) buildings which are not technical devices or their teams, the operation of which may cause an emission.

Due to the limitation indicated above in accordance with Art. 3 points. 48) Environmental Protection Act multimodal container terminal does not meet the definition of "establishment", as confirmed by Art. 248, paragraph 2, point 2a saying that the provision of paragraph. 1 Art. 248 of the Act shall not apply to road transport, rail, inland waterway, sea or air dangerous substances and directly related to the temporary holding them outside the establishment, including loading and unloading and transport to and from the docks, wharves and marshalling yards.

Due to above for multimodal container terminals shall not apply to the Environment Protection Act regarding plants with increased or high risk of serious industrial accident. Therefore, it is not required to develop relevant documentation, among others, Application plant, a program to prevent accidents, the safety report or an internal operational plan - rescue. To the same conclusion can be reached by analyzing the provisions contained in the Directive of the European Parliament and of the Council 2012/18 / EU of 4 July 2012. On the control of major accident hazards involving dangerous substances, hereinafter referred to as Directive 
Seveso III, whose implementation into Polish law are among others the provisions of Title IV of the Major Accidents Environment Protection Act.

According to Article 1 point. 2 c) Seveso III Directive shall not apply to "road, rail, inland waterway, sea or air of dangerous substances and directly related to the temporary holding them outside the establishments covered by this Directive, including loading and unloading cargo and transport to and docks, wharves and marshalling yards. "

It must be admitted that due to the temporary storage of hazardous substances in multimodal container terminal may lead to a major accident causing danger toxic, explosive or fire.

In Art. 244 of the Law of Environmental Protection legislator clearly states that the operator whose activities may be the cause of a breakdown, the operator transporting dangerous substances, and the authorities are obliged to protect the environment against failures.

Precisely for this reason, for multimodal container terminal it is worth developed and brought into use emergency plan for the terminal along the lines of the plan required under Art. 261 of the Law of Environmental Protection and thus ensure the safety of the work involved in trading container.

It is worth to work out operational - rescue plan for the terminal include:

1. The characteristics of the risks to the main groups of dangerous goods stored in the terminal,

2. The rules of storage and segregation of containers,

3. In case of emergency events related to the performance of the logistics operations of containers

4. The arrangements for informing and warning of the dangers

5. Rules evacuation and description of professional conduct after the threat,

6. The analysis of hazards zones in case of an uncontrolled release of a representative of hazardous substances.

In the next part of this paper, I would like to focus on two basic elements of the operational rescue plan for the terminal: the rules of storage and segregation of containers and analysis of the risks in case of an uncontrolled release of hazardous substances.

\section{Rules of storage and segregation of containers}

1. containers containing dangerous goods prior to the adoption of the square container should be evaluated in terms of the technical condition and the accuracy of labeling.

2. elaborate rules of segregation of containers containing dangerous goods. An example of such rules defined in the following table segregated. 


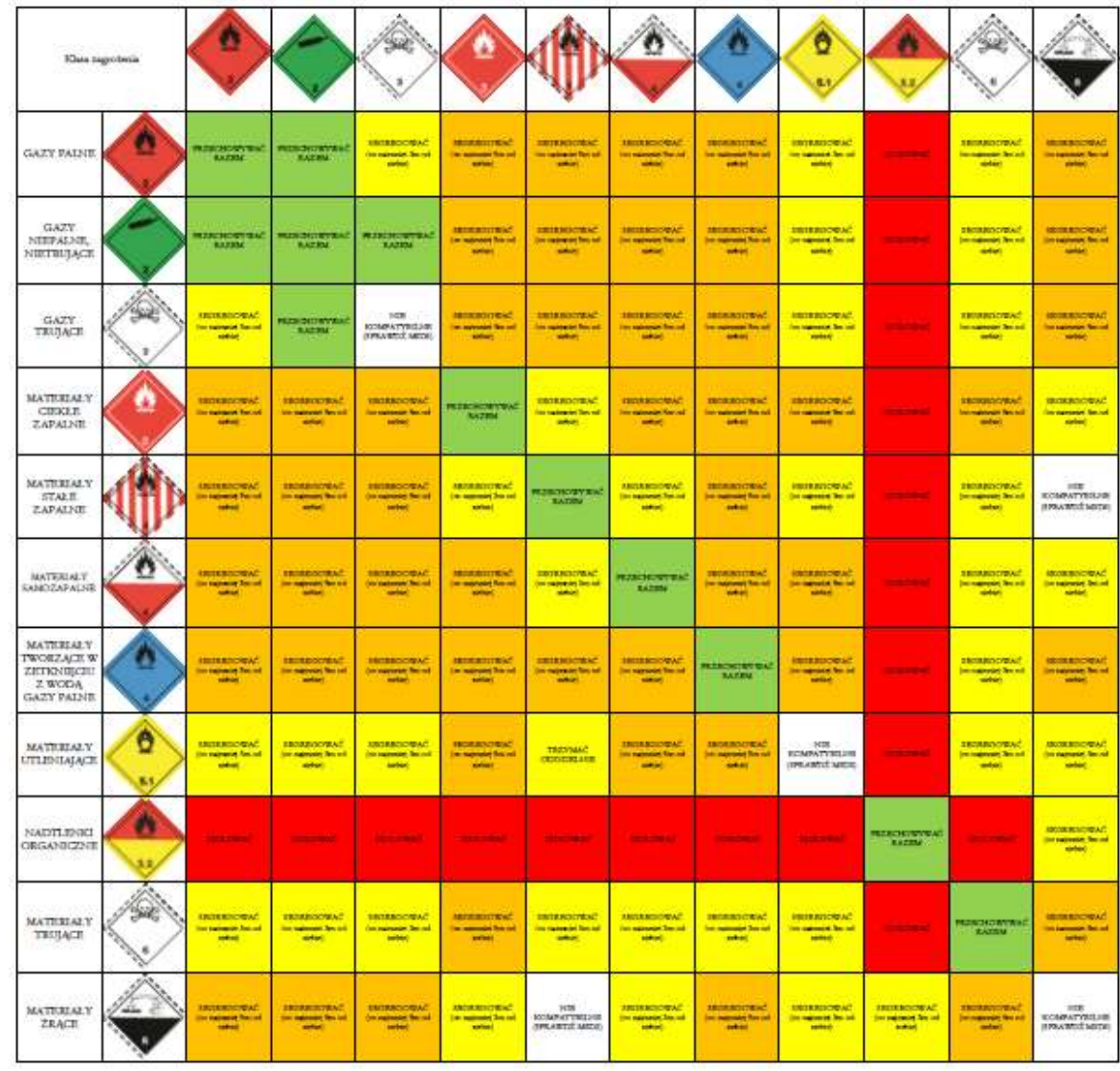

Good solution segregation storage of dangerous goods are given in Table 2 of the Guidelines TRGS 510 "Storage of hazardous substances in the non-stationary tanks" issued by the German Federal Institute for Occupational Safety and Health (BAuA). You can also use the requirements set out in section 7 of the International Maritime Code for Dangerous Goods Code ( IMDG) issued by the International Maritime Organisation (IMO).

1. It is recommended to not proliferate other containers with containers reservoir type.

2. Where the dangerous goods creates more than one hazard (eg. Is flammable and poisonous) should be based on the UN number and packing group (if have applicable) to adopt and apply the principles of segregation for dominant threat. An example of hazard identification dominant shown below

\section{Example}

The choice of the dominant threat to the UN 1017 Chlorine:

a) check the UN number for chlorine (eg. with a warning sign ADR / RID)

b) in Table A of Chapter 3.2 of ADR / RID (Fig. below), we search the issue of the UN dangerous goods.

c) check the compliance of the Group Packaging (if affect) based on the transport document.

d) in the column "sticker" read the dominant threat - the first digit without the "+" 


\begin{tabular}{|c|c|c|c|c|c|c|c|c|c|c|c|c|c|}
\hline \multirow[t]{3}{*}{ is } & \multirow[t]{2}{*}{ Nerwa i appir } & \multirow[t]{2}{*}{ Kians } & \multirow{2}{*}{ 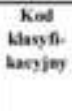 } & \multirow{2}{*}{$\begin{array}{l}\text { Craps } \\
\text { pats } \\
\text { matis }\end{array}$} & \multirow[t]{2}{*}{ Naicpu| } & \multirow{2}{*}{ 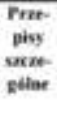 } & \multicolumn{2}{|c|}{ nesti } & \multicolumn{3}{|c|}{ Foliemanit } & \multicolumn{2}{|c|}{ 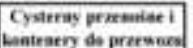 } \\
\hline & & & & & & & equatike & inglepenest & 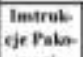 & 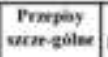 & $\begin{array}{c}\text { Prepring } \\
\text { patows-nis }\end{array}$ & $\begin{array}{l}\text { Totrut } \\
\text { jet }\end{array}$ & $\begin{array}{l}\text { Prepeiny } \\
\text { owereghtare }\end{array}$ \\
\hline & 3.1 .2 & 2.2 & 2.2 & 21.1 .3 & 5.22 & 3.3 & 3.4 .6 & 3.5 .2 & 4.1 .4 & 4.4 & 4.1.16 & $\frac{4.52}{73.2}$ & $4.2 .5,3$ \\
\hline (1) & (2) & (3a) & (3b) & (4) & (5) & (6) & (a) & $(7 \mathrm{~b})$ & (8) & (9n) & $\left(9 b_{1}\right)$ & (10) & (II) \\
\hline & EWUTHESE, WEGLA & & & & & 653 & & & & & & & \\
\hline 1016 & TLENEK WEGL SPREZONY & 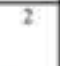 & ITI & & $\begin{array}{l}23 \\
+21\end{array}$ & & 100 & E0 & $F 200$ & & MP9 & (M) & \\
\hline का17 & cruose & 2 & $2 \pi O C$ & & 239 & & 100 & Eil & $\$ 200$ & & MPQ9 & $\begin{array}{l}(\mathrm{M}) \\
\mathrm{T} 90\end{array}$ & $T P 19$ \\
\hline 1018 & 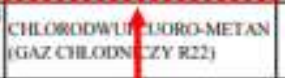 & $\frac{2}{2}$ & $2 A$ & $\uparrow$ & 22 & & & EI & क200 & & MP9 & $\begin{array}{l}\text { (M) } \\
\mathrm{T} 50\end{array}$ & \\
\hline & $\begin{array}{l}\text { 1. Whszukujerny po numerze U } \\
\text { identylikowary towar }\end{array}$ & & & $\begin{array}{l}\text { 2. Sprawd. } \\
\text { fo ile doty }\end{array}$ & $\begin{array}{l}\text { ramy ro } \\
\text { cry). }\end{array}$ & & & & & $\begin{array}{l}\text { dczytujemy } \\
\text { wszy numer } \\
\text { ver } 2.3-\text { Gaz }\end{array}$ & 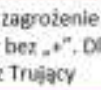 & $\begin{array}{l}\text { dominutia } \\
\text { sctiliorut }\end{array}$ & opdzile to \\
\hline
\end{tabular}

1. It is recommended that universal containers with dangerous goods were stored up to 3 layers.

2. It is recommended that tank containers with dangerous goods can be stored up to 2 layers.

3. Tank Containers will be segregate on the basis as for other containers.

4. It is recommended that containers of goods class 4.2 and class 5.2 may be stored only in one layer.

5. Containers of hazardous materials must be stored in a way that allows easy access transport equipment, fire fighting (eg. Fire hydrants) and, in the case of events with containers of appropriate emergency services.

6. Containers of hazardous materials must be in the sectors and locations where it is possible their constant observation by the workers or security service.

7. Empty uncleaned containers / tank containers, which have contained dangerous goods or contain residues of hazardous materials are stored and segregate on the principles applicable to containers with dangerous goods classes that recently were in the container.

\section{Analysis of the risks in case of an uncontrolled release of hazardous substances.}

In order to determine the potential danger areas arising in the event of accidents involving container, can be carried out computer simulation of the spread of threats using computer programs such. PHAST, SAFETI, ALOHA Hazard Analysis should be performed by estimating the conditions and effects of physical threats that can occur following the occurrence of events container, which lead to the release of hazardous material to the outside environment.

Typical risks associated with the release of hazardous substances, depending on their properties include the toxicological (related to the dispersion of a toxic gas in the air), fire (the harmful radiation and emission of fumes - products of combustion) and the explosion / explosion (impact wave pressure) .

Type of hazard depends on many factors, primarily on the properties of the material the properties of the release of substance, weather conditions, topography, the type and manner of release, and possible interactions with the environment. 
As indicators of the effects and physical effects can be applied by the appropriate parameter values for individual hazard. The following tables are examples of threshold values for concentrations of toxic substances, hypertension and thermal radiation, together with the expected potential consequences for people and estate.

Zones fire hazard

\begin{tabular}{|c|c|c|}
\hline $\begin{array}{c}\text { The effect type } \\
\text { (radiacja termiczna) }\end{array}$ & Effects to humans & Effects on estate \\
\hline $\mathbf{3 7 , 5} \mathbf{k W} / \mathbf{m}^{\mathbf{2}}$ & $\begin{array}{c}100 \% \text { mortality within 1 min- } \\
1 \% \text { of deaths within } 10 \\
\text { seconds. }\end{array}$ & $\begin{array}{c}\text { Damage to apparatus and } \\
\text { devices }\end{array}$ \\
\hline $\mathbf{1 2 , 5} \mathbf{k W} / \mathbf{m}^{\mathbf{2}}$ & $\begin{array}{c}50 \% \text { mortality within 1 min } \\
\text { of serious injury for } 10 \\
\text { seconds. }\end{array}$ & $\begin{array}{c}\text { Secondary fires of flammable } \\
\text { materials }\end{array}$ \\
\hline $\mathbf{4} \mathbf{k W} / \mathbf{m}^{\mathbf{2}}$ & $\begin{array}{c}0 \% \text { of deaths, burns causes } \\
\text { pain after 20 seconds. }\end{array}$ & - \\
\hline
\end{tabular}

Zones toxic danger

\begin{tabular}{|c|c|}
\hline ERPG-1 & $\begin{array}{l}\text { the concentration of toxic substances in the air, which in the } \\
\text { one-hour exposure causes only mild, reversible symptoms of } \\
\text { health or exceeds the threshold Odor }\end{array}$ \\
\hline ERPG-2 & $\begin{array}{l}\text { the concentration of toxic substances in the air, which in the } \\
\text { one-hour exposure will not cause serious, irreversible health } \\
\text { effects, and does not limit the ability of people to evacuate }\end{array}$ \\
\hline ERPG-3 & $\begin{array}{l}\text { the concentration of toxic substances in the air, which in } \\
\text { one-hour exposure does not cause a direct threat to life }\end{array}$ \\
\hline IDLH & $\begin{array}{l}\text { the concentration of toxic substances in the air, which in } \\
\text { healthy employees will not cause life-threatening health } \\
\text { effects or limit their ability to evacuate }\end{array}$ \\
\hline NDS & $\begin{array}{l}\text { value weighted average concentration of the impact on the } \\
\text { employee during an 8-hour daily and average weekly } \\
\text { working time provided for in the Labour Code, the period of } \\
\text { its activity should not cause negative changes in his state of } \\
\text { health and the health of the future generations }\end{array}$ \\
\hline NDSCh & $\begin{array}{l}\text { the maximum instantaneous concentration - the average } \\
\text { value of the certain concentration, a toxic chemical } \\
\text { compound that should not cause negative changes in the } \\
\text { health of the worker, whether in the workplace no longer } \\
\text { than } 15 \text { minutes and not more than } 2 \text { times during a shift in } \\
\text { the interval of not less than one hour. }\end{array}$ \\
\hline AEGL-1 & $\begin{array}{l}\text { concentration of a substance above which predictably } \\
\text { general population may experience discomfort, irritation, or } \\
\text { certain asymptomatic contamination effects (all effects are } \\
\text { transient and reversible). }\end{array}$ \\
\hline AEGL-2 & $\begin{array}{l}\text { concentration of a substance above which predictably } \\
\text { general population may experience irreversible or serious, } \\
\text { long-term effects of adverse health or deteriorate the ability } \\
\text { to be self-evacuation. }\end{array}$ \\
\hline
\end{tabular}




\begin{tabular}{|c|l|}
\hline \multirow{2}{*}{ AEGL-3 } & $\begin{array}{l}\text { concentration of a substance above which predictably } \\
\text { general population may experience the effects of directly } \\
\text { threatening the life or die. }\end{array}$ \\
\hline
\end{tabular}

* Set of the values threshold concentrations ERPG (The Emergency Response Planning Guideline values) has been developed by the American Industrial Hygiene Association (AIHA) for substances for which there is some data on their impact on the human body.

** Concentrations AEGLs (Acute Exposure Guideline Levels) describe the results of medical effects in people exposed to the toxic substance.

\section{Zones explosion threats}

\begin{tabular}{|c|c|}
\hline $\begin{array}{c}\text { The effect type } \\
\text { (hypertension wave) }\end{array}$ & Effects to humans and the environment \\
\hline $0,05 \mathrm{~atm}$ & pressure glass breakage \\
\hline $0,20 \mathrm{~atm}$ & medium and serious injuries \\
\hline $0,45 \mathrm{~atm}$ & partial destruction of buildings, damaged walls and roofs \\
\hline
\end{tabular}

\section{An example of a hazard analysis for the release of the container tank of propane}

For calculations in the analyzed scenario assumed flow of propane from a damaged tanker of the container (assumed degree of filling of $80 \%$ ) of the slots having a length of $10 \mathrm{~cm}$ and a height of $1 \mathrm{~cm}$, leakage to $1 / 5$ of the height of the container tank. Propane coming from the leak directly into the atmosphere will pose toxicological hazard, fire and explosion. The following is a graphic representation of potentially explosive propane.

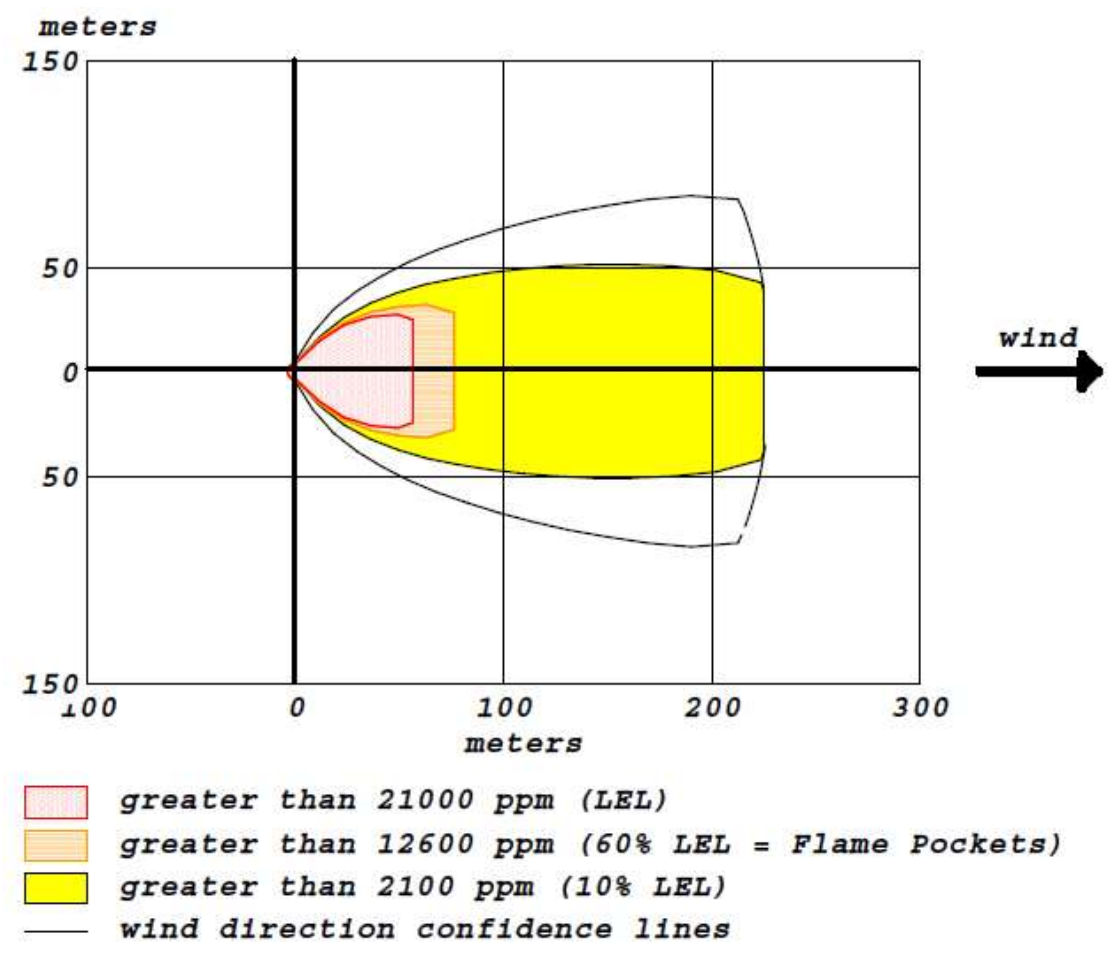

\section{Summary}

Developed and implemented the use of emergency plan for the terminal allows for proper preparation of the infrastructure and operation of the terminal on the occurrence of a major accident. Not without significance is the systematic exercise the effectiveness of its activities and its improvement. 
Which in turn will allow you to avoid the situation that took place in China in Tianjin on August 12 2015. where 139 people were killed, 34 were found to be missing, and more than 700 people were injured. Chinese authorities then ordered the evacuation of thousands of residents within a radius of three kilometers from the explosion site. Until the outbreak occurred in the warehouse, which stored hazardous substances. The explosion caused a huge fire. As it turned out, the company to which he belonged magazine, had a permit for the storage of dangerous substances for only two months, but kept them in the warehouse for a year. In the warehouse, there were 700 tons of sodium cyanide - 70 times more than it should be stored in one place. There was also ammonium nitrate, which is a component of many explosives. In the vicinity of a huge explosion in Tianjin found to exceed acceptable levels of cyanide, even 356 times.

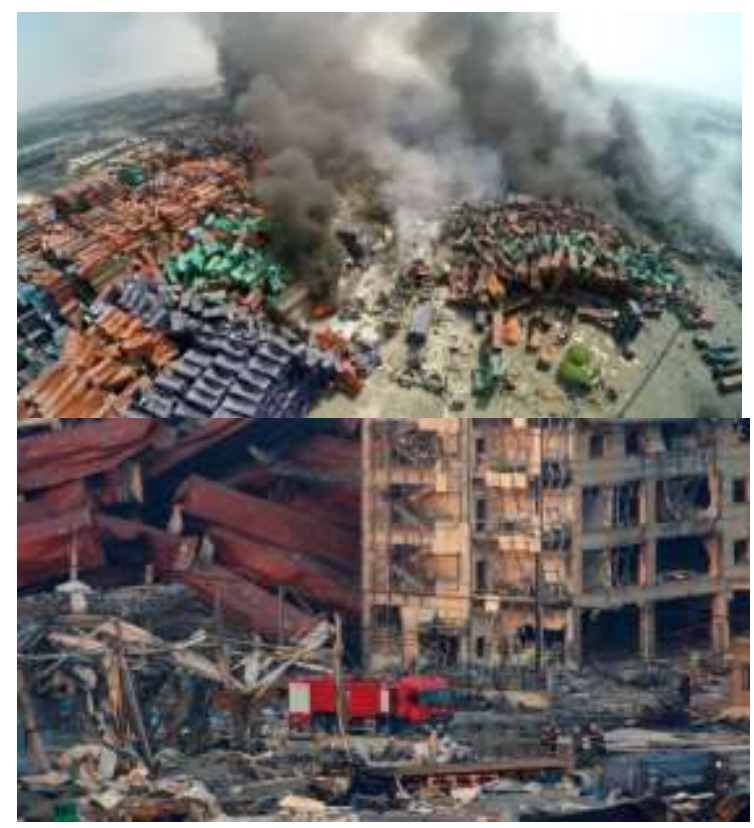

